\title{
Dimensions and Antecedents of Relationship Quality in a Business-to-Business Context: An Exploratory Study
}

\author{
Karima Ghzaiel $^{1}$ and Fathi Akrout ${ }^{2}$ \\ ${ }^{1}$ LRM, Chebba, Tunisia \\ ${ }^{2}$ LRM, Sfax, Tunisia
}

\begin{abstract}
This research seeks to provide insights into seller-perceived relationship quality in the Business-to-Business context. A qualitative study was conducted through interviews with sixteen sellers from multiple sectors to identify dimensions and antecedents of buyer-seller relationships quality.

In light of the findings stemming from thematic and lexical analysis, four dimensions of relationship quality have emerged: mutual trust, partners' commitment in the relationship, cooperation and conflict. Also, the research identifies several key success factors in business relationships that are grouped into different categories: factors related to characteristics of the two relationship parties, factors related to relational behaviors and factors related to characteristics of the offer. These results serve as valuable indicators, allowing managers to evaluate, adjust and develop their relationships marketing strategies. They also provide a tool for improving sales force managing. This study provides a significant contribution to the relationship quality literature and it helps to settle controversies on this subject. In addition, directions for further research have been suggested.
\end{abstract}

Keywords: relationship quality, seller, business-to-business markets, qualitative study, thematic analysis, lexical analysis.

\section{Introduction}

In light of the new directions (intense competition, perpetual changing environment), the researchers note a real orientation toward a relational marketing at the expense of transactional marketing (Paun, 1997; Weitz and Bradford, 1999). As a reaction, some companies have adopted a relational selling strategy. However, to profit from this strategy, the seller is required to make efforts to develop and maintain good relationships with his/her customers (Dwyer et al., 1987).

In this regard, several researchers postulated that the relationship quality is a suitable solution for the vendor to assess the nature and the intensity of customer relationships and to develop a competitive advantage which is difficult to duplicate by his competitors (Hennig-Thurau et al., 2002; Wong et al., 2007).

Other researchers added that relational marketing and relationship quality are most appropriate in particular settings (Palmatier et al., 2006), such as the Business-to-Business area because of the substantial financial investments (Lendrevie et al., 2003), the limited number of potential customers, the complexity of decision making process (Malaval, 1996) and the importance of interpersonal interactions (O'Malley and Tynan, 2000). This is consistent with some other

Copyright (C) 2012 Karima Ghzaiel and Fathi Akrout. This is an open access article distributed under the Creative Commons Attribution License unported 3.0, which permits unrestricted use, distribution, and reproduction in any medium, provided that original work is properly cited. Contact author: Karima Ghzaiel E-mail: ghzaeil_karima@yahoo.fr 
reserchers' ideas postulating that relationship quality is more important in certain situations marked by high degrees of uncertainty, long delivery times, a great vulnerability to opportunistic behaviors, etc (Berry, 1983; Crosby et al., 1990).

Therefore, the construct of relationship quality has been a subject of a significant number of researches in marketing in order to achieve a better understanding of its dimensions and determinants (Parsons, 2002; Holmlund, 2008; Athanasopoulou, 2008). However, in analyzing the various studies on this subject, a lack of consensus is noted regarding its constitution and its antecedents (Myhal et al, 2008). The results appear to vary depending on the context (BtoB, BtoC) and the perspective (buyer, seller, dyad) studied (Walter et al., 2003; Vieira et al, 2008).

It should be noted that most approaches to quality relationship conceptualization that have been proposed have neglected the seller's perspective. Indeed, the subject has been predominantly treated from the customer's perspective (Crosby et al., 1990; Dorsch et al., 1998; Parsons, 2002; Lin and Ding, 2005; Ulaga and Eggert, 2006; Chen et al., 2008). In this respect, Vieira et al. (2008) presumed that "this gap is probably due to the difficulties inherent to collecting and analyzing data from both sides of the dyad" (p. 271). Thus, the authors hereof responded to the call of several researchers, who emphasized the need to study relationship quality from the seller's point of view (Parsons, 2002; Ivens, 2004; Wong et al., 2007) as a way of achieving a better understanding of this construct. To attain this objective, we were elected to carry out a qualitative study, alongside a few researchers (Wong and Sohal, 2002; Ashnai et al., 2009). In fact, only a few numbers of researchers (Burca et al., 2004; Huntley, 2006; Athanasopoulou, 2008) have conducted such studies in certain specific contexts.

Therefore, the authors thought it is appropriate to conduct an exploratory qualitative study on vendors operating specifically in the field of Business-toBusiness to explore their perception of the customer relationship quality and to identify its determinants.

This paper is structured as follows. It begins with a theoretical overview on the construct of relationship quality. Then, the research design is presented. Subsequently, the findings that stemmed from the thematic and lexical analysis and managerial implications are outlined. In the last section, the authors summarize the main conclusions of the study, point out its limitations and propose directions for future research.

\section{Theoretical Framework}

In spite of the multiplicity of studies on the relationship quality, few researchers and practitioners share a common definition of this construct(Athanasopoulou, 2008; Qin et al., 2009). The overview of the various proposed definitions reveals different ways of relationship quality conceptualization (Walsh et al., 2010). Some scholars (Hennig-Thurau and Klee, 1997) define it by reference to the physical quality of goods and services expected by customers from their sellers. On the other hand, some other researchers (Crosby et al., 1990; Bejou et al., 1996; Smith, 1998) rather incorporate the relation's social aspect in the definition of relationship quality. In fact, this construct seems to create a link between the two parts of the exchange, allowing them to reap benefits beyond the simple exchange of goods and services (Ford, 1980).

Another group of studies has focused on the dynamic character of this construct (Järvelin, 2001; Moliner et al., 2007). According to this line of thinking, relationship quality consists of a dynamic process that changes with relation development (Gronroos, 2007).

This lack of consensus may be attributed to the limited number of sophisticated discussions concerning its conceptualisation (Hennig-Thurau, 2000), the relationships diversity (Woo and Ennew, 2004), and the nature of this construct, which is specific to the context studied (Athanasopoulou, 2008). Indeed, 
various definitions of relationship quality have been proposed in specific contexts: Business-to-Business (Lang and Colgate, 2003; Huntley, 2006; Ashnai et al., 2009), retail area (Hennig-Thurau, 2000 ; De Wulf et al., 2001; Vesel and Zabkar, 2010) and service sector (Crosby et al., 1990 ; Roberts et al., 2003; Moliner et al., 2007).

What emerges from the different conceptualizations discussed in the literature is that this construct is generally understood as an overall assessment of the interaction between the two parties of the exchange (De Wulf, 2001; Garbarino and Johnson, 1999; Hennig-Thurau et al., 2002). For example, according to Johnson (1999), the relationship quality describes the depth and climate of the relationship. It is also commonly admitted that relationship quality is a condition to build long term relationships (Crosby et al., 1990; Bejou et al., 1996).

To overcome this lack of consensus regarding the relationship quality definition, we adopt the idea of Bagozzi (1984) postulating that the meaning of a concept is rooted in its characteristics. This idea is also asserted by Woo and Ennew (2004), who proposed that «in order to progress the conceptualization of relationship quality... we should accept a very general perspective on the meaning of the term, (...) and focus instead on identifying the constructs that create relationship quality» (p.1256).

In what follows, the various dimensions of relationship quality will be presented. Then, the authors its antecedents will be exposed.

\section{Dimensions of Relationship Quality}

Crosby et al. (1990) were the first to define the relationship quality as when «the customer is able to rely on the salesperson's integrity and has confidence in the salesperson's future performance because the level of past performance has been consistently satisfactory» (p70). By defining it as such, the relationship quality is then considered a higher-order construct composed of two dimensions: trust in the salesperson and satisfaction with the salesperson (Crosby et al., 1990).

This conceptualization has served as a support for subsequent studies considering the relationship quality as a multidimensional construct incorporating several distinct, although interrelated, indicators reflecting the global nature of the relationship between the exchange partners (Kumar et al., 1995; De Wulf et al., 2001; Hennig Thurau et al., 2002; Lin and Ding, 2005). Indeed, a minority of scholars (Wong and Sohal 2002; Ndubisi, 2006) opted for a unidimensional concept of this construct.

The literature review shows that several studies (Lagace et al., 1991; Wray et al., 1994; Bejou et al., 1996; Boles et al., 2000; Parsons 2002 ; Liu et al., 2011) tended to implement the relationship quality conceptualization adopted by Crosby et al (1990) using the same dimensions; namely, satisfaction and trust. Several other researchers (Lang and Colgate, 2003; Keating et al., 2003; Ivens, 2004; Fynes et al., 2005; Huntley 2006) expanded this list by incorporating new dimensions. It is in this context that Ben Naoui and Zaiem (2010) proposed a classification of the different dimensions proposed into three main categories. The first category includes indicators of dimensions referring to behavioral intentions, such as affective conflict (Kumar et al., 1995; Skarmeas and Robson, 2008), communication (Anderson et Narus, 1990; Adjei et al., 2009), opportunism (Dwyer et al., 1987; Dorsch et al., 1998), the ethical profile (Lagace et al., 1991; Wray et al., 1994 ; Bejou et al., 1996), cooperation (Fynes et al., 2004 ; Cater and Cater, 2010), adaptation (Woo and Ennew, 2004; Fynes et al., 2004), etc. The second category contains relational indicators, such as trust (Crosby et al., 1990; Ganesan, 1994), satisfaction (Crosby et al., 1990; De Wulf et al., 2001), commitment (Morgan et Hunt, 1994; Fournier, 1998), etc. The last group of dimensions includes indicators of the results of exchange relation ${ }_{2}$ such as economic benefits (Berry, 1995; Naudé and Buttle, 2000), mutual objectives (Wilson, 1995), equity of the relation (Johnson, 
1999; Kumar et al., 1995), proximity (Barnes, 1997), etc.

The abundance of proposed dimensions reflects the lack of consensus among researchers (Vieira et al, 2008). The majority of dimensions used are reported in the table below.

Tablel. Dimensions of relationship quality

\begin{tabular}{|c|c|c|c|c|c|c|}
\hline \multirow[t]{2}{*}{ Autors } & \multicolumn{4}{|c|}{ Dimensions of relationship quality } & \multirow[t]{2}{*}{ Sector } & \multirow[t]{2}{*}{ Perspective } \\
\hline & Satisfaction & Trust & Commitment & Others & & \\
\hline $\begin{array}{l}\text { Crosby et } \\
\text { al }(1990)\end{array}$ & $\mathrm{x}$ & $\mathbf{x}$ & & & Service & Buyer \\
\hline $\begin{array}{l}\text { Kumar et } \\
\text { al (1995) }\end{array}$ & & $\mathbf{x}$ & $\mathbf{x}$ & $\begin{array}{l}\text { Affective and manifest } \\
\text { conflict, willingness to } \\
\text { invest, expectations of } \\
\text { continvity }\end{array}$ & $\begin{array}{l}\text { Automobile } \\
\text { distribution }\end{array}$ & Buyer \\
\hline $\begin{array}{l}\text { Dorsch et } \\
\text { a. (1998) }\end{array}$ & $\mathbf{x}$ & $\mathbf{x}$ & $x$ & $\begin{array}{l}\text { opportunism, customer } \\
\text { orientation, } \\
\text { prosle }\end{array}$ & Service & Buyer \\
\hline $\begin{array}{l}\text { S mith } \\
(1998)\end{array}$ & $x$ & $x$ & $x$ & & $\begin{array}{l}\text { Business to } \\
\text { Business }\end{array}$ & \\
\hline $\begin{array}{l}\text { Baker et al } \\
\text { (1999) }\end{array}$ & $\mathbf{x}$ & $\mathbf{x}$ & $\mathbf{x}$ & cooperation & $\begin{array}{l}\text { Business to } \\
\text { Business }\end{array}$ & Seller \\
\hline $\begin{array}{l}\text { Navde and } \\
\text { Buttle } \\
(2000)\end{array}$ & $x$ & $\mathbf{x}$ & & $\begin{array}{l}\text { cooránation,power, } \\
\text { prost }\end{array}$ & $\begin{array}{l}\text { Business to } \\
\text { Business }\end{array}$ & Buyer \\
\hline $\begin{array}{l}\text { (De Wulf } \\
\text { et al, 2001) }\end{array}$ & $\mathbf{x}$ & $x$ & $x$ & & Distribution & Buyer \\
\hline $\begin{array}{l}\text { Hewett et } \\
\text { al }(2002)\end{array}$ & & 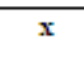 & $x$ & & $\begin{array}{l}\text { Business to } \\
\text { Business }\end{array}$ & \\
\hline $\begin{array}{l}\text { Walter et } \\
\text { al }(2003)\end{array}$ & $x$ & $x$ & $x$ & & $\begin{array}{l}\text { Business to } \\
\text { Business }\end{array}$ & Buyer \\
\hline $\begin{array}{l}\text { Roberts et } \\
\text { al }(2003)\end{array}$ & $x$ & $x$ & $x$ & affective conflict & $\begin{array}{l}\text { Indus triel } \\
\text { service }\end{array}$ & Buyer \\
\hline $\begin{array}{l}\text { Woo and } \\
\text { Ennew } \\
(2004)\end{array}$ & & & & $\begin{array}{l}\text { Cooperation, } \\
\text { atmosphere, adaptation }\end{array}$ & $\begin{array}{l}\text { Business to } \\
\text { Business }\end{array}$ & Buyer \\
\hline $\begin{array}{l}\text { (Fynes et } \\
a 1,2004)\end{array}$ & & $\mathbf{x}$ & & $\begin{array}{l}\text { adaptation, } \\
\text { communication, } \\
\text { cooperation }\end{array}$ & $\begin{array}{l}\text { Busines to } \\
\text { business }\end{array}$ & Seller \\
\hline $\begin{array}{l}\text { Ivens and } \\
\text { Pardo } \\
(2007)\end{array}$ & $x$ & $\mathbf{x}$ & $\mathbf{x}$ & & $\begin{array}{l}\text { Business to } \\
\text { Business }\end{array}$ & \\
\hline $\begin{array}{l}\text { Holmlund } \\
(2008)\end{array}$ & & & & $\begin{array}{l}\text { Techric dimension, } \\
\text { social dimension, } \\
\text { economic dimension }\end{array}$ & $\begin{array}{l}\text { Business to } \\
\text { Business }\end{array}$ & Dyad \\
\hline $\begin{array}{l}\text { De } \\
\text { Cannière et } \\
\text { at }(2010)\end{array}$ & $\mathbf{x}$ & $\mathbf{x}$ & $\mathbf{x}$ & & Retail & Buyer \\
\hline
\end{tabular}

Summing up and analyzing the above studies, it is noted that the relationship quality is generally conceptualized as a higher order construct, but there is a lack of consensus regarding the number and nature of dimensions used. As noted by Athanasopoulou (2009), controversies are more important in Business-to-Business than in retail studies. In fact, in the former setting, the dimensions chosen vary widely across studies. However, despite this discrepancy, the authors note the dominance of certain dimensions, namely satisfaction, commitment, and trust.

\section{Antecedents of Relationship Quality}

Other studies have further focused on the major antecedents of relationship quality. The emerging factors are found to vary, depending on the context studied (Walter et al., 2003) and the dimensionality of the relationship quality adopted (Vieira et al., 2008). They often tend to merge with the 
dimensions of this concept (Wilson, 1995; Roberts et al., 2003). Generally, they can be classified into four major categories (Athanasopoulou, 2009). The first includes the characteristics and behaviors of both sides of the partner exchange (Boles et al., 2000), ethical behavior of the salesperson (Lagace et al., 1991), seller expertise (Crosby et al., 1990; Wray et al., 1994), reputation and size of supplier firm (Doney and Cannon, 1997), the level of centralization and formalization of firms (Dwyer et al., 1987), customer orientation (Baker et al., 1999), etc.

The characteristics of the relationship are grouped into the second category. Essentially, they consist of the duration of the relationship (Bejou et al., 1996), the partners dependence (Van Bruggen et al., 2005), communication quality (Morgan et Hunt, 1994), cooperation (Ruyeter et al., 2001), conflict handling (Selnes, 1998), equity (Kumar et al., 1995), trust (Moorman et al., 1992; Ndubisi, 2006), commitment (Selnes, 1998; Ndubisi, 2006), etc. The third category includes the offer characteristics, such as service quality, product performance and after-sales service (Ruyeter et al., 2001; Roberts et al., 2003). The latest group incorporates the environment attributes (Kumar et al., 1995).

In Business-to-Business setting, the antecedents mostly used consist essentially of seller expertise, its size and reputation, the relationship length, the degree of formalization, the characteristics of the offer, the conflict handling, the quality of communication between the two parties and their cooperation (Athanasopoulou, 2009).

To sum up, the authors can underscore the abundance of literature on the concept of relationship quality. Several studies have focused primarily on the study of its determinants and dimensions without providing an exhaustive model that can be widely adopted in different contexts. In order to better conceptualize the relationship quality in Business-toBusiness area, it seems interesting to conduct a qualitative study from seller perspective, which has been neglected in most previous studies (Vieira et al, 2008). This research will be in line with several researchers admitting relationship quality as a mega construct composed of different indicators and the authors will try to identify its major dimensions in this area as well as the factors facilitating or inhibiting it.

\section{Research Methodology}

This section describes the research methodology implemented in the present study. First, the study's population will be presented. Then, the data collection method will be discussed. Lastly, the authors will describe the qualitative data analysis method.

\section{Field of Investigation and Sample Study}

The authors chose to conduct the study in Business-to-Business setting in which relationship quality has a great importance given the specificities of the latter, such as the limited number of potential customers, the interpersonal interactions importance, the decision making process complexity (Malaval, 1996; O'Malley and Tynan, 2000), etc.

The seller's perspective will be examined, which has usually been ignored in most approaches to relationship quality conceptualizations (Crosby et al., 1990; Dorsch et al., 1998; Parsons, 2002; Chen et al., 2008).

Sixteen interviews were conducted with vendors operating in various sectors (industry, commerce, parapharmaceutical industry) to collect rich data. Their number was not determined beforehand. In fact, the sample size was determined by the criterion of saturation (Drapeau, 2004). At the sixteenth interview, the authors felt that there was no new evidence and they decided to stop. They considered that such a size was sufficient for the purposes of the study since the respondents mentioned various ideas and situations. 


\section{Data Collection}

In this study, the authors chose to conduct in depth interviews to ensure the wealth of collected information. The interviewing period lasted on average between 35 and 40 minutes. They were centered on the following three open-ended questions:

- What are the characteristics of a good relationship with your customer?

- What are the factors that facilitate the development of a good relationship between customer and seller?

- Which factors prevent the development of a good relationship between customer and seller?

The interviews were tape-recorded, allowing the retention of rich information when transcribing interviews. The outset is with a brief presentation of the context and the research subject.

To analyze the collected data, the authors opted for a content analysis procedure following the different steps of Giannelloni and Vernette (2002).

In order to ensure the external validity of this research (Evrard et al, 2003), the qualitative data were analyzed using thematic and lexical analysis. Both types of analysis are presented in the following sections.

\section{Qualitative Data Analysis}

\section{Thematic Analysis}

Accordingly to Pallemans (1999), thematic analysis consists of "cutting the data into pieces or units of content and, then, ranking in a number of subdivisions" (p171).

To do this, the data collected have been fully transcribed. Although this stage was long and meticulous, it provided rich information. In order to determine dominant themes addressed by the respondents, all answers were structured in tabulated form. The selection of the main themes took into account the objectives of the study (Gionnelloni and Vernette, 2003).

Each interview was analyzed in accordance with this coding grid, taking into account the presence of the theme and the number of times it was mentioned by the respondent. For each individual "i", the authors assigned a speech corresponding to the theme. Then, a horizontal analysis was used in order to check how each theme was addressed by respondents.

\section{Lexical Analysis}

The thematic analysis was combined with a lexical analysis using Lexico3, a qualitative data analysis software developed by Lebart and Salem (1994).This type of analysis is widely deployed in marketing (GavartPerret and Moscarola, 1998) owing to developing software for qualitative data analysis (Evrard et al, 2003). This analysis "focuses on the study of words in the text...it proceeds to the examination of repeated elements, that is to say the text lexicon review" (Mathieu, 2004, p70).

It was deemed worthy to follow such analysis for two major reasons. First, it is an automated technique allowing to save time and to minimize subjectivity to a low degree. It also allows considering the environment of studied words and identifying graphic forms with the highest occurrence frequencies (Gavart-Perret et Moscarola, 1998). Also, it permits highlighting all the lexicometric characteristics of the data collected to draw factual explanations. In order to ensure a successful analysis, a preparation stage is conducted. First, the interviewees' corpus is entered in Word. Then, a dictionary is developed. Ganassali (2008) describes this method in the following terms, stating that "Each theme is associated with a series of words and phrases (...) to indicate the presence of the theme in the response" (p. 63). Then, the answers are segmented into $n$ parts, called "elementary units of contexts." These consist of various terms that correspond to a particular idea. This fragmentation is 
performed taking into account the themes from the thematic analysis.

\section{Results}

In what follows, presented are the results stemming from the thematic analysis combined with those stemming from the lexical analysis. First, the presentation of the different dimensions of relationship quality is elaborated. Then, discussed are the factors that were identified by the vendors as being likely to influence the success of such a relationship quality in a Business-to-Business context.

\section{Dimensions of Relationship Quality}

When asked about the characteristics of a good relationship between the seller and the customer, respondents identified several indicators, such as mutual trust, two party commitment in the relationship, cooperation and absence of conflict.

The main themes that have emerged from the analysis and their occurence frequency (calculated using Lexico3) are summarized in table2. They will be discussed below.

Table : Frequency of relationship quality dimensions

\begin{tabular}{l|ll}
\hline \multicolumn{1}{c|}{ Themes } & \multicolumn{2}{c}{$\begin{array}{c}\text { Cumulative frequency } \\
\text { Absolv te }\end{array}$} \\
\multicolumn{2}{c}{ Dimensions of relationchip quality } \\
\hline Mutual trust & 81 & $44.5 \%$ \\
\hline $\begin{array}{l}\text { The two parties commitment } \\
\text { in the relationship }\end{array}$ & 52 & $28.6 \%$ \\
Cooperation & 25 & $13.7 \%$ \\
\hline Conflit & 24 & $13.2 \%$ \\
Total & 182 & $100 \%$ \\
\hline
\end{tabular}

\section{$\underline{\text { Mutual Trust }}$}

From content analysis, the preeminence of the theme of trust between the two relatiponship parties becomes apparent. Indeed, the frequency of this theme shows that respondents consider trust a central indicator of relationship quality. It is assimilated to "cement of the relationship» (Individual7) and "without it, we don't talk about a good relationship» (Individual 13). In fact, "everything is based on mutual trust» (Individual5). According to respondents, trust is usually associated with tranquility. "To say that $x$ is a good customer or with whom I have a good relationship, I must feel at ease with him » (Individual 5). Also, "in a good relationship, the customer feels quiet and safe» (Individual 2).

Furthermore, this theme includes honesty and keeping one's promise. In fact, «the customer is also assessed on his promises respect. Sometimes, there are commands that are placed over the phone reflecting a climate of trust between us. It is interesting to respect our commitments with our customer. On the other hand, he must keep his promises especially concerning the deadlines for payment» (Individual 2).

Partner benevolence was also often mentioned by respondents: "In shortage or crisis times, we try to serve, firstly, our customers in order not to disrupt their activities. This is because we know that when our company has problems, they will help us to overcome difficulties» (Individual 8). "Everything is based on mutual trust. The customer feels valued and he feels that I am concerned with his interests and aware of his constraints and financial terms» (Individual 5) and "(...) he relies on our support in difficult times» (individual 2).

To sum up, the authors note that two dimensions of trust have been mentioned by several respondents; namely, trust in the benevolence of the partner and trust in his/her honesty. This result corresponds to those of the lexical analysis. In fact, the form group analysis relative to the theme of trust highlights the preponderance of 
forms like trust, trustful, honesty, quiet, promise, support, safety, etc

\section{The Commitment of Both Parties in the Relationship}

Talking about their customer relationship quality, several sellers referred to the commitment of both parties in the relationship. The latter is perceived as «an implicit partnership that develops between the two parties» (Individual 8). In fact, «the seller and the customer feel comfortable and aim for the continuity of their relationship» (Individual 9). According to the respondents, the customer expresses his commitment "by buying from his partner even if he finds other offers more profitable and he recommends the former to others " (Individual7). "He considers the seller as a friend or brother to whom he may disclose his personal problems» (Individual6) and "he hopes that the seller visits and calls him to remain in contact » (Individual4).

For his part, Individual 8 stated that «the seller is often patient and he tolerates the late payment of the latter, even if this could disrupt his activity »

\section{Conflict}

Although it is less prominent than the other dimensions of relational quality, lack of conflict is a key indicator of a good relationship between the vendor and his customers. Indeed, respondents reported that "generally, there are not conflicts or problems» (Individual5) and "there is an atmosphere of trust devoid of any tensions or doubts despite the conflict of interests of both parties » (Individual4).

This theme coincides with the idea of some researchers viewing conflict as a negative indicator of relationship quality (Kumar et al., 1995; Roberts et al., 2003). It reflects the hostility and anger felt by the individual toward his partner (Brown et al., 1991).

\section{Cooperation}

Cooperation is a fact for several respondents. «To succeed their activities, the two relationship partiescan work together byconstantlysharing useful information allowing them to protect themselves against certain events or to promote their relationship. They may work together to find solutions to problems that exist on the market, such as certain practices of competitors or other customers » (individual2). Similarly, «the customer can help his partner to develop a new product on the market» (Individual1).

In addition to thematic analysis, lexical analysis made possible the analysis of concordances and to return to the text in order to study each form in its immediate environment (Gavart-Perret and Moscarola, 1998). Thus, the authors systematically returned to the discourse of the interviewees to identify the location of each dimension. This helped to decide whether it is a dimension or an antecedent of relationship quality. This analysis also paved the way to ensure the relevance of the themes that emerged as dimensions of relational quality.

In conclusion, it is noted that by enhancing the quality of their relationships with customers, the vendors seem to attribute great importance to the social aspect of the relationship. The dimensions identified are close to those adopted by several studies (Kumar et al., 1995; Roberts et al., 2003), namely the absence of conflict, the mutual trust between exchange partners, their commitment and their cooperation.

\section{Determinants of Relationship Quality}

With reference to the results of the content analysis, several determinants of relational quality were identified, which were grouped into three different categories. The first category includes factors related to the characteristics of both sides of the relationship, while the second brings together the factors reflecting the characteristics of the relationship. The last category includes factors related to the offer characteristics. 
The antecedents of the relationship quality stemming from the thematic analysis and their frequency are summarized in table 3 below.

T able 3: Frequency of the antecedents of relationship quality

\begin{tabular}{|c|c|c|}
\hline \multirow[t]{2}{*}{ Themes } & \multicolumn{2}{|c|}{ Cumulative frequency } \\
\hline & Absolvte & Relative \\
\hline \multicolumn{3}{|c|}{ Antecedents of relationship quality } \\
\hline Characteriatics of the seller & 45 & 29 \\
\hline Characteristics of the customer & 34 & 21,7 \\
\hline Characteriatics of the offer & 24 & 15,3 \\
\hline Relational behaviours & 53 & 34 \\
\hline T otal & 156 & $100 \%$ \\
\hline
\end{tabular}

\section{Characteristics of the Seller}

Several respondents emphasized that «the customer feels more comfortable when he realizes that the seller is mastering the specificities of his product, especially in our area, where the product is sophisticated and requires technical explanations to convince the customer and to reassure him that it meets his expectations» (Individual 4).

Thus, this characteristic seems to depend on the nature of the product. According to the respondents, the most important qualities of the seller are social. They consist of the seller's honesty and transparency. Indeed, «to get a successful relationship with the customer, the seller must be honest and transparent with his client from the beginning of the transaction. Their relationship looks like that of two fiancés. If there is a lack of transparency between the two partners, they can't go further » (Individual 3).

It was also pointed out that the seller must be open, friendly, courteous and polite with his customer in order to adapt to all customers' profiles. He must also show concern for the well being of others. «He must avoid manipulations, lies and deceit and he must keep in mind that such practices are prohibited by Allah" (Individual 5).

\section{Characteristics of the Customer}

Although it seems unusual to talk about client characteristics as factors influencing the quality of the relationship, the authors note that sellers give importance to the personality and behavior of the customer to judge the quality of their relationships with them. They particularly emphasized that the customer must be creditworthy and that he must keep promises related to payment deadlines. Similarly, it seems obvious that they prefer the customer who is transparent and that "respects and accepts the seller's advice and proposals» (Individual9). Being comprehensive is also important. «The customer must avoid excessive negotiation that often causes a climate of tension between the two parties» (Individual10). At this level, one respondent remarked that being comprehensive may be dependent on the customer's age and his education level. He stated that «older customers with whom we work usually have low levels of education. This prevents us from showing them invoices or other data that would allow us to convince them when they go far in their negotiations » (Individual7). 


\section{$\underline{\text { Relational Behaviors }}$}

The relational behaviors identified reflect mainly the following factors:

\section{- Customer Orientation:}

The seller should focus on the customer to determine his/her needs and satisfy his/her desires. Indeed, «it is very important to see things from the customer's perspective. Being aware about his situation and his limits, the seller can best help him " (Individual9).In this way, the seller can help the customer to state his/her needs precisely. He can also recommend the most appropriate products that satisfy his/her needs. He can also avoid various techniques of manipulation or pressure.

\section{- Adaptive Selling Behavior}

Each customer has a specific character. Therefore, "the vendor must be flexible enough to operate with different customer profiles» (Individual 7). This requires that "at the beginning of the interaction, the seller must first try to discover the customer's character» (Individual 4).

\section{- Listening to Consumers}

"Listening to consumer is very important in determining relationship success. Always, listening to our customers allows us to collect much information concerning their needs and requirements " (Individual 3). "Subsequently, this data allows the company to improve the quality of its offer, its communication, etc » (Individual 7).

\section{- Conflict Handling}

Conflicts prevent the two parties from maintaining their relationship. Therefore, "the seller should quickly resolve manifest conflicts and handle customer's complaints through finding the appropriate solutions that reconcile the interests of both parties. Such behavior allows building relationships without problems» (Individual 2). "Sometimes, a good management of a customer's claim can be a starting point for a good relationship between seller and customer» (Individual 8).

\section{- Communication Quality}

Several interviewees seem aware of the importance of communication quality between the two sides of the exchange to guarantee the quality of their relationships. "We need our clients to provide us with the maximum amount of information relating to their activity, their situation, as well as to their competitors' practices, which may affect the sector. For example, when we are aware that golden customers practice dumping, we must stop them to protect others» (Individual 2). "We hope that the information provided by our customers is reliable but, always, we should make sure of its credibility» (Individual 8). "In turn, the seller must avoid concealing relevant information to this customer» (Individual 10).

An additional respondent added the following «We must exchange useful information with our customers, including those who are at the first stages of their business. These are usually so motivated and ambitious that they can give us useful facts allowing us to correct strategies or to prevent certain changes in the sector» (Individual 2).

\section{The Characteristics of the Offer}

The content analysis shows that the characteristics of the offer can affect the quality of the relationship between the customer and the seller. For example, the quality of the product is a crucial determinant of such a relationship quality. Indeed, "selling a good quality product allows vendor to gain his customer satisfaction» (Individual 2) and "prevents him from resorting to cheating, lies and manipulation of the customer. So, this paves the way for establishing an atmosphere of trust between the two relationship parties» (Individual 1).

The quality of the after-sale service is also a crucial determinant of the relationship quality. «We must follow the customer after purchase and offer him the best guarantees. $\mathrm{He}$ will then feel respected and not manipulated » (Individual 9). «This 
especially improves his satisfaction and his trust in the seller» (Individual 12).

\section{Discussion}

The results of this study corroborate those of several previous research studies. Concerning dimensions of the customer relationship quality, it is found that the most predominant themes that have been raised by the sellers match the dimensions that have been adopted by researchers in various contexts, and more specifically, in a Business-to-Business context, namely trust in the exchange partner (Morgan and Hunt, 1994; Baker et al., 1999; Liu et al., 2010), commitment of the two parties in the relationship (Morgan and Hunt, 1994 ; Friman et al., 2002; Liu et al., 2010), cooperation (Baker et al., 1999; Fynes et al., 2004; Woo and Ennew, 2004; Cater and Cater, 2010) and minimal conflict (Kumar et al., 1995; Roberts et al., 2003).

Only trust in the benevolence of the partner and trust in his honesty were mentioned by the respondents. As for the third dimension of trust, trust in the competence of the partner, it was not mentioned by respondents. Thus, the findings provide support to the contention of some researchers postulating that these two indicators are two central dimensions in the literature on the evaluation of interpersonal relationships (Anderson and Narus, 1990, Crosby et al., 1990; Ganesan, 1994; Roberts et al., 2003).

Similarly, through the customer interviews, it appears that the sellers' evaluation of their relationship quality revolves around the psychological bond between the two partners and their desire to maintain their relationship which is similar to a partnership. In fact, respondents focused rather on the affective and temporal commitment at the expense of the calculator commitment, which often reflects an opportunistic behavior and a search for significant alternatives (Mimouni and Volle, 2003). In fact, this may depend on the relationship specificities in the Business-to-Business setting. The seller tends to give enormous importance to the relational aspect in his interaction with the customer at the expense of benefit seeking.

In addition to the factors of trust and commitment in the relationship, the importance of cooperation is also observed. Thus, the authors hereof share the view of some researchers (Woo and Ennew, 2004) postulating that it is a behavioral manifestation of trust and commitment, whose presence reflects a relationship of good quality. Combined with interpersonal trust and conflict, this indicator reflects respectively the social dimension of the relationship quality (Cater and Cater, 2010) and the atmosphere of the relationship (Hakansson and Snehota, 1995).

The dimensions of the relational quality stemming from the above analysis focus mainly on the social aspect of the relationship. This justifies why some authors subsumed them under one dimension called social dimension of relational quality (Burca et al, 2004; Holmlund, 2008) or atmosphere (Woo and Ennew, 2004).

However, these results are not consistent with those of some researchers (Burca et al, 2004; Holmlund, 2008), who postulated that relationship quality is composed of a social dimension, an economic dimension (profit) and a technical dimension (product or service quality). Also, some other researchers (Baker et al, 1999; Fynes et al, 2004; Woo and Ennew, 2004) have incorporated other indicators as dimensions of this construct, such as communication and adaptation, whereas in the present study, these relational behaviors are conceptualized as antecedents to relationship quality. So, this study is thus getting closer to the conceptualization proposed by several researchers (Bejou et al., 1996; Boles et al., 2000; Ruyeter et al., 2001; Friman et al., 2002). 
In addition, the characteristics of the seller are perceived to be quite important (Doney and Cannon, 1997; Smith, 1998). Similarly, the results of the study support Athanasopoulou's idea (2008), which highlights the importance of the customer characteristics. Both parties of the relationship should be honest, comprehensive, open, respectful, polite, etc.

Like other seller characteristics and behaviors (seller reputation, customer orientation, adaptive selling behavior), the similarity of both sides was considered to be antecedent to the relationship quality (Crosby et al, 1990; Doney and Cannon, 1997; Boles et al, 2000). Several previous researchers (Doney and Cannon, 1997; Baker et al, 1999; Cheng et al, 2008) investigated their impact on the quality of customer relationship and particularly on the two partners' satisfaction and trust (Bejou et al, 1996).

Finally, the product performance and the after-sales service quality seem to correlate with the relationship quality. Such an impact has been proved by Ruyeter et al. (2001).

\section{Managerial Implications}

Relationship quality represents an important asset allowing maintaining and developing ongoing customer relationship (Hennig-Thurau et al., 2002; Roberts et al., 2003; Wong et al., 2007). Therefore, it must be well managed. Managers should always assess their business relationships to improve their quality and to ensure their customers retention (or to keep their customers). The dimensions and antecedents of relationship quality stemming from the previous analysis serve as valuable indicators, allowing managers to evaluate, adjust, and develop their relationship marketing strategies. Similarly, the study provides a tool for improving sales force management. In particular, the antecedents of relationship quality that are related to the characteristics of the seller should be used as selection criteria for his recruitment. The latter must be open, honest, sociable, courteous, comprehensive, etc.
Also, the factors related to the skills and relational behaviors of the seller should be taken into consideration so as to provide efficient training in a number of skills, such as listening, adaptive selling, communication, etc.

To encourage the vendor to learn such skills and implement such conducts, a positive culture must prevail at the firm. Indeed, working in an atmosphere characterized by honesty, good communication, cooperation, mutual respect, benevolence, etc, allows the seller to respect and to adopt such principles when dealing with customers.

Finally, given that offer characteristics are considered determinants of the relationship quality by respondents, the managers should then take into consideration the technical aspect of the relationship in addition to the relational side. Indeed, they should provide a good quality product as well as a good after-sales service to best suit the needs of their customers and ensure their satisfaction.

\section{Conclusion}

The aim of this exploratory study is to provide a better understanding of the concept of relationship quality in a Business-to-Business setting. The study provides a number of theoretical contributions. In fact, it contributes new insights to the relationship quality literature and, consequently, helps to settle a number of controversies. In addition, it offers a valuable tool, allowing academics to evaluate the quality of buyer-seller relationships. The study has also attempted to fill in the gap in the research on relationship quality by examining the seller's perspective, a factor which has been widely neglected by previous research. Thus, the interview analysis has provided several dimensions reflecting the seller-perceived relationship quality. Lastly, the study has made it possible to determine several factors that can enhance or inhibit such relationship quality. 
The present study is not without limitations. The sample used is not fully representative of the studied community. Therefore, the present study's results lack generalizability. These limitations point out the need to refine and validate this conceptualization inherent to the Businessto-Business setting.

Also, the study focused basically on the seller's perspective in order to overcome gaps in the literature. Therefore, it remains important to conduct dyad studies to discover whether sellers and customers perceive their relationship quality differently in the same area.

Furthermore, future research should study other different types of relationships such as retail relationships (product, service). Further studies should, also, check if dimensions and antecedents of the relationship quality perceived by the seller vary across different context (For example B-to-B and B-to-C).

Finally, taking into account that relationship quality is considered a dynamic construct by some researchers (Moliner et al, 2007; Gronroos, 2007), the authors call for other studies to examine whether such conceptualization varies depending on the relationship development.

\section{Bibliography}

Adjei, M. T., Griffith, D. A. \& Noble, S. M. (2009). "When Do Relationships Pay off for Small Retailers? Exploring Targets and Contexts to Understand the Value of Relationship Marketing," Journal of Retailing, 85 (4), Pp. 493-501.

Anderson, J. C. \& Narus, J. A. (1990). "A Model of Distributor Firm and Manufacturer Firm Working Partnerships," Journal of Marketing, 54 (1), Pp. 42-58.

Ashnai, B., Smirnova, M., Kouchtch, S., Yu, Q., Barnes, B. R. \& Naudé, P. (2009). "Assessing Relationship Quality in Four Business-to-Business Markets," Marketing Intelligence and Planning, 27 (1), Pp. 86102.
Athanasopoulou, P. (2008). "Antecedents and Consequences of Relationship Quality in Athletic Services," Managing Service Quality, 18 (5), Pp. 479-495.

Athanasopoulou, P. (2009). "Relationship Quality: A Critical Literature Review and Research Agenda," European Journal of Marketing, 43 (5/6), Pp. 583-610.

Bagozzi, R. P. (1984). "A Prospectus for Theory Construction in Marketing," Journal of Marketing, 54 (1), Pp. 42-58.

Baker, T. L., Simpson, P. M. \& Siguaw, J. A. (1999). "The Impact of Suppliers' Perceptions of Reseller Market Orientation on Key Relationship Constructs," Journal of the Academy of Marketing Science, 27 (1), Pp. 50-57.

Barnes, J. G. (1997). "Closeness Strength, and Satisfaction: Examining the Nature of Relationships between Providers of Financial Services and Their Retail Customers," Psychology and Marketing, 14 (8), Pp. 765-790.

Bejou, D., Wray, B. \& Ingram, T. N. (1996). "Determinants of Relationship Quality: An Artificial Neural Network Analysis," Journal of Business Research, 36 (2), Pp. 137-143.

Ben Naoui, F. \& Zaiem, I. (2010). "The Impact of Relationship Quality on Client's Loyalty: An Application in the Parapharmaceutical Industry," International Journal of Pharmaceutical and Healthcare Marketing, 4 (2), Pp. 137-156.

Berry, L. L. (1995). "Relationship Marketing of Services-Growing Interest, Emerging Perspectives," Journal of the Academy of Marketing Science, 23 (4), 236-245.

Boles, J. S., Johnson, J. T. \& Barksdale, H. C. (2000). "How Salespearson Build Quality Relationships: A Replication and Extension," Journal of Business Research, 48 (1), Pp. 75-81.

Burca, S., Fynes, B. \& Roche, E. (2004). 'Evaluating Relationship Quality in A Business-to-Business Context,' Irish Journal of Management, 25 (2), Pp. 61-75. 
Cater, T. \& Cater, B. (2010). "Product and Relationship Quality Influence on Customer Commitment and Loyalty in B2B Manufacturing Relationships," Industrial Marketing Management, 39, Pp. 1321-1333.

Chen, Z. X., Shi, Y. \& Dong, D.- H. (2008). "An Empirical Study of Relationship Quality in a Service Setting: A Chinese Case," Marketing Intelligence and Planning, 26 (1), Pp. 11-25.

Crosby, L. A., Evans, K. R. \& Cowles, D. (1990, July). "Relationship Quality in Services Selling: An Interpersonal Influence Perspective," Journal of Marketing, 54 (3), Pp. 68-81.

Dash, S., Bruning, E. \& Guin, K. K. (2006). "The Moderating Effect of Power Distance on Perceived Interdependance and Relationship Quality in Commercial Banking: A Cross-Cultural Comparaison," International Journal of Bank Marketing, 24 (5), Pp. 307-326.

De Cannière, M. H., De Pelsmacker, P. \& Geuens, M. (2010, Marsh). "Relationship Quality and Purchase Intention and Behavior: The Moderating Impact of Relationship Strength," Journal of Business and Psychology, 25 (1), Pp. 87-98.

De Wulf, K., Odekerken-Schroder, G. \& Iacobucci, D. (2001, Oct). "Investments in Consumer Relationships: A Cross-Country and Cross- Industry Exploration," Journal of Marketing, 65 (4), Pp. 33-50.

Doney, P. M. \& Cannon, J. P. (1997, April). "An Examination of the Nature of Trust in Buyer-Seller Relationships," Journal of Marketing, 61, Pp. 35-51.

Dorsch, M. J., Swanson, S. R. \& Kelley, S. W. (1998). "The Role of Relationship Quality in the Stratification of Vendors as Perceived by Customers," Journal of the Academy of Marketing Science, 26 (2), Pp. 128-142.

Drapeau, M. (2004). "Les Critères De Scientificité En Recherche Qualitative," Pratiques Psychologiques, 10, Pp. 79-86.
Dwyer, F. R., Schurr, P. H. \& Oh, S. (1987). "Developing Buyer-Seller Relationships," Journal of Marketing, 51, Pp. 11-27.

Ford, D. (1980). "The Development of Buyer-Seller Relationships in Industrial Markets," European Journal of Marketing, 14 (5/6), Pp. 339-353.

Fournier, S. (1998). "Consumers and Their Brands: Developping Relationship Theory in Consumer Research," Journal of Consumer Research, 24 (4), 343-373.

Friman, M., Garling, T., Millet, B., Mattsson, J. \& Johnston, R. (2002). "An Analysis of International Business-to-Business Relationships Based on the CommitmentTrust Theory," Industrial Marketing Management, 31, Pp. 403-409.

Fynes, B., De Burca, S. \& Marshall, D. (2004). "Environmental Uncertainty, Supply Chain Relationship Quality and Performance," Journal of Purchasing and Supply Management, 10 (4/5), Pp. 179-190.

Fynes, B., Voss, C. \& Burca, S. (2005). "The Impact of Supply Chain Relationship Quality on Quality Performance," International Journal of Production Economies, 96, Pp. 339-354.

Ganassali, S. (2008, Juillet-Septembre). "Faire Parler Les Mots: Vers Un Cadre Méthodologique Pour L'analyse Thématique Des Réponses Aux Questions Ouvertes," Décisions Marketing, (51, 55-67.

Ganesan, S. (1994). "Determinants of LongTerm Orientation in Buyer-Seller Relationships," Journal of Marketing, 58, Pp. 1-19.

Garbarino, E. \& Johnson, M. S. (1999). "The Different Roles of Satisfaction, Trust, and Commitment in Customer Relationships," Journal of Marketing, 63 (2), Pp. 70-87.

Gavart-Perret, M.- L. \& Moscarola, J. (1998). 'De L'énoncé a L'énonciation : Pour Une Relecture De L'analyse Lexicale En Marketing,' Recherche et Applications En Marketing, 13 (2), P. 31. 
Giannelloni, J. \& Vernette, E. (2002). 'Etudes De Marché,' Paris: Vuibert.

Gronroos, C. (2007). Service Management and Marketing: customer management in service competition. New York: John Wiley and Sons.

Hakansson, H. \& Snehota, I. (1995). Developing Relationships in Business Networks. Londres: Routledge.

Hennig-Thurau, T. (2000). "Relationship Quality and Consumer Retention Through Strategic Comunication of Customer Skills," Journal of Marketing Management, 16 (1/3), Pp. 55-79.

Hennig-Thurau, T., Gwnner, K. P. \& Gremler, D. D. (2002, Feb). "Understanding Relationship Marketing Outcomes: An Integration of Relational Benefits and Relationship Quality," Journal of Service Research, 4 (3), Pp. 230-247.

Hennig-Thurau, T. \& Klee, A. (1997, Dec). "The Impact of Customer Satisfaction and Relationship Quality on Customer Retention: A Critical Reassessement and Model Development," Psychology and Marketing, 14 (18), Pp. 737-75.

Hewett, K., Money, R. B. \& Sharma, S. (2002). "An Exploration of the Moderation Role of Buyer Corporate Culture in Industrial Buyer-Seller Relationships," Journal of the Academy of Marketing Science, 30 (3), Pp. 229-239.

Holmlund, M. (2008). "A Definition, Model, and Empirical Analysis of Business-toBusiness Relationship Quality," International Journal of Service Industry Management, 19 (1), Pp. 32-62.

Huntley, J. K. (2006). "Conceptualization and Measurement of Relationship Quality: Linking Relationship Quality to Actual Sales and Recommendation Intention," Industrial Marketing Management, 35, Pp. 703-714.

Ivens, B. S. (2004). "Industrial Seller' Relational Behavior: Relational Styles and Their Impact on Relationship Quality,"
Journal of Relationship Marketing, 3 (4), Pp. 27-43.

Ivens, B. S. \& Pardo, C. (2007). "Are Key Account Relationsips Different? Empirical Results on Supplier Strategies and Customer Reactions," Industrial Marketing Management, 36 (4), Pp. 470-482.

Järvelin, A. M. (2001). Evaluation of Relationship Quality in Business Relationships.Ph.D.University of Tampere,Tampere.

Johnson, J. L. (1999). "Strategic Integration in Industrial Distribution Channels: Managing the Interfirm Relationship as a Strategic Asset," Journal of the Academy of Marketing Science, 27 (1), Pp. 4-18.

Keating, B., Rugimbana, R. \& Guazi, A. (2003). "Differenciating between Service Quality and Relationship Quality in Cyberscape," Managing Service Quality, 13 (3), Pp. 217-232.

Kumar, N., Scheer, L. K. \& Steenkamp, J. B. E. M. (1995, February). "The Effects of Supplier Fairness on Vulnerable Resellers," Journal of Marketing Research, 32, Pp. 5465.

Lagace, R. R., Dahlstrom, R. \& Gassenheimer, J. B. (1991). "The Relevance of Ethical Salesperson Behavior on Relationship Quality: The Pharmaceutical Industry," Journal of Personal Selling and Sales Management, 4, Pp. 39-47.

Lang, B. \& Colgate, M. (2003). "Relationship Quality, On-Line Banking and the Information Techology Gap," International Journal of Bank Marketing, 21 (1), Pp. 5465.

Lebart, L. \& Salem, A. (1994). Statistique Textuelle. Paris: Dunod.

Lendrevie, J., Levy, J. \& Lindon, D. (2003). Mercator (Ed. 7ème Edition). Dalloz.

Lin, C.- P. \& Ding, C. G. (2005). "Opening the Black Box: Assessing the Mediating Mechanism of Relationship Quality and the Modrating Effects of Prior Experience in 
ISP Service," International Journal of Service Industry Management, 16 (1), Pp. 55-80.

Liu, C.- T., Guo, Y. M. \& Lee, C.- H. (2011). "The Effects of Relationship Quality and Switching Barriers on Customer Loyalty," International Journal of Information Management, 31, Pp. 71-79.

Liu, Y., Li, Y. \& Zhang, L. (2010). "Control Mechanisms Across a Buyer-Supplier Relationship Quality Matrix," Journal of Business Research, 63, Pp. 3-12.

Malaval, P. (1996). 'Marketing Business-toBusiness,' Editions Publi-Union.

Mathieu, J. P. (2004, Avril-Juin). "L'analyse Lexicale Par Contexte: Une Méthode Pertinente Pour La Recherche Exploratoire En Marketing," Décisions Marketing, (34), Pp. 67-77.

Moliner, M. A., Sanchez, J., Ridriguez, R. M. \& Callarisa, L. (2007). "Relationship Quality with a Travel Agency: The Influence of the Post Purchase Perceived Value of a Tourism Package," Tourism and Hospitality Research, 7 (3/4), Pp. 194-211.

Moorman, C., Zaltman, G. \& Deshpandé, R. (1992). "Relationship between Providers and Users in Market Research: The Dynamics of Trust Within and between Organizations," Journal of Marketing Research, 29, Pp. 314-328.

Morgan, R. M. \& Hunt, S. D. (1994). "The Commitment-Trust Theory of Relationship Marketing," Journal of Marketing, 58 (3), Pp. 20-38.

Naudé, P. \& Buttle, F. (2000). "Assessing Relationship Quality", Industrial Marketing Management, 29 (4), Pp. 351-361.

Ndubisi, N. O. (2006). "A Structural Equation Modelling of the Antecedents of Relationship Quality in the Malaysia Banking Sector," Journal of Financial Services Marketing, 11 (2), Pp. 131-141.

O'Malley, L. \& Tynan, C. (2000). "Relationship Marketing in Consumer
Markets: Rhetoric or Reality?," European Journal of Marketing, 34 (7), Pp. 797-815.

Pallemans, P. (1999). Recherches Qualitatives en Marketing: Perspective Psychologique. De Boeck Université.

Palmatier, R., Dant, R., Grewal, D. \& Evans, K. (2006). "Factors Influencing the Effectiveness of Relationship Marketing: A Meta-Analysis," Journal of Marketing, 70 (4), 136-153.

Parsons, A. L. (2002, Spring). "What Determines Buyer-Seller Relationship Quality? An Investigation from the Buyer's Perspective," Journal of Supply Chain Management, 38 (2), Pp. 4-12.

Paun, D. A. (1997). "A Study of "Best" Versus Average Buyer-Seller Relationships," Journal of Business Research, 29 (1), Pp. 13-21.

Pras, B., Evrard, Y. \& Roux, E. (2003). Market-Etudes et Recherches En Marketing, 3ème Ed.Paris: Dunod.

Qin, S., Zhao, L. \& Yi, X. (2009). "Impacts of Customer Service on Relationship Quality: An Empirical Study in China," Managing Service Quality, 19 (4), 391-409.

Roberts, K., Varki, S. \& Brodie, R. (2003). "Measuring the Quality of Relationships in Consumer Services: An Empirical Study," European Journal of Marketing, 37 (1/2), Pp. 169-196.

Ruyeter, K., Moorman, L. \& Lemmink, J. (2001). "Antecedents of Commitment and Trust in Customer-Supplier Relationships in High Technology Markets," Industrial Marketing Management, 30 (3), Pp. 271286.

Selnes, F. (1998). "Antecedents and Consequences of Trust and Satisfaction in Buyer-Seller," European Journal of Marketing, 32 (3/4), Pp. 305-322.

Skarmeas, D. \& Robson, M. J. (2008). "Determinants of Relationship Quality in Importer-Exporter Relationships," British Journal of Management, 19, Pp. 171-184. 
Smith, J. B. (1998). "Buyer-Seller Relationships: Similarity, Relationship Management, and Quality," Psychology \& Marketing, 15 (1), Pp. 3 - 21.

Ulaga, W. \& Eggert, A. (2006). "Relationship Value and Relationship Quality: Broadening the Nomological Network of Business-to Business Relationships," European Journal of Marketing, 40 (3/4), Pp. 311-327.

Van Bruggen, G. H., Kacher, M. \& Nieuwlaat, C. (2005). "The Impact of Channel Function Performance on Buyer-Seller Relationships in Marketing Channels," International Journal of Research in Markeing, 22 (2), Pp. 141-158.

Vesel, P. \& Zabkar, V. (2010). "Relationship Quality Evaluation in Retailers' Relationships with Consumers," European Journal of Marketing, 44 (9/10), Pp. 13341365.

Vieira, A. L., Winklhofer, H. \& Ennew, C. T. (2008). "Relationship Quality: A Literature Review and Research Agenda," Journal of Customer Behavior, 7 (4), Pp. 269-291.

Volle, P. \& Mimouni, A. (2003). "Bénéfices Perçus De La Fidélisation et Qualité Relationnelle : Une Application Exploratoire $\mathrm{Au}$ Secteur Du Transport Aérien," Actes Du 19ème Congrès International De L'afm, (Pp. 1-28). Gammarth-Tunis.

Walsh, G., Hennig-Thurau, T., Sassenberg, K. \& Bornemann, D. (2010). "Does Relationship Quality Matter in E-Services? A Comparaison of Online and Offline Retailing," Journal of Retailing and Consumers Services, 17, Pp. 130-142.

Walter, A., Muller, T. A., Helfert, G. \& Ritter, T. (2003). "Functions of Industrial Supplier Relationships and Their Impact on Relationship Quality," Industrial Marketing Management, 32 (2), Pp. 159 - 169.

Weitz, B. A. \& Bradford, K. D. (1999). "Personal Selling and Sales Management: A Relationship Marketing Perspective," Journal of the Academy of Marketing Science, 27, 2, Pp. 241-254.
Wilson, D. T. (1995). "An Integrated Model of Buyer-Seller Relationships," Journal of the Academy of Marketing Science, 23, 4, 3545.

Wong, A. \& Sohal, A. (2002). "An Examination of the Relationship between Trust, Commitment and Relationship Quality," International Journal of Retail and Distribution Management, 30 (1), Pp. 34-50.

Wong, Y., Hung, H. \& Chow, W. K. (2007). "Mediating Effects of Relationship Quality on Consumer Relationship: An Empirical Study in Hong Kong," Marketing Intelligence \& Planning, 25 (6), Pp. 581-596.

Woo, K. S. \& Ennew, C. T. (2004). "Businessto-Business Relationship Quality: An IMP Interaction-Based Conceptualization and Measurement," European Journal of Marketing, 38 (9/10), Pp. 1252-1271.

Wray, B., Palmer, A. \& Bejou, D. (1994). "Using Neural Network Analysis to Evaluate Buyer-Seller Relationships," European Journal of Marketing, 28 (10), Pp. 32-48. 